\title{
CEO Emotional Intelligence and Firms' Financial Policies. Bayesian Network Method
}

\author{
Mohamed Ali Azouzi', Anis Jarboui' ${ }^{1}$
}

\begin{abstract}
The aim of this paper is to explore the determinants of firms' financial policies according to the manager's psychological characteristics. More specifically, it examines the links between emotional intelligence, decision biases and the effectiveness of firms' financial policies. The article finds that the main cause of an organization's problems is the CEO's emotional intelligence level. We introduce an approach based on Bayesian network techniques with a series of semi-directive interviews. The research paper represents an original approach because it characterizes behavioral corporate policy choices in emerging markets. To the best of our knowledge, this is the first study in the Tunisian context to explore this area of research. Our results show that Tunisian leaders adjust their decisions (on investments and distributions) to minimize the risk of loss of compensation or reputation. They opt for decisions that minimize agency costs, transaction costs, and cognitive costs.
\end{abstract}

KEY WORDS: $\quad$ emotional intelligence; corporate finance; optimism; overconfidence; loss aversion; financial policy; Bayesian network

JEL Classification: G14, G31, G32, D80

${ }^{1}$ University of Sfax, Tunisia

\section{Introduction}

Recent research has focused on the importance of emotion as it relates to intellectual abilities, particularly in organizations that evaluate employees' abilities in terms of emotions rather than cognition (Brackett et al., 2006). The importance of emotional intelligence is emphasized because human relations in organizations are affected by emotional factors more than rational factors. The emotional quotient is as important as the intelligence quotient; indeed, the emotional intelligence of individuals who carry out duties and play essential roles in ensuring organizational outcomes is quite significant. Therefore,

Correspondence concerning this article should be addressed to: Mohamed Ali Azouzi, ISAAS, BP 1013 - 3018 Sfax-Tunisia E-mail: Mohamed_azouzi@yahoo.fr successful organizations require employees who can communicate effectively, control their emotions, and demonstrate their technical abilities (Fiori, 2009).

The implications of managerial characteristics on corporate decisions have only recently begun to be explored by behavioral finance researchers. The literature in behavioral finance departs from the traditional financial model to incorporate psychological evidence on non-standard preferences and beliefs. This approach examines the consequences of CEO behavioral biases based on such preferences and beliefs as loss aversion, optimism, overconfidence, etc., which are traits that have been shown to be prevalent in managers. The studies attempt to determine whether CEOs' financial decisions are distorted by such behavioral biases (Azouzi \& Jarboui, 2012; Backer, Ruback, \& Wurgler, 
2004; Hackbarth, 2009; Hawkins, Hoch, \& MeyersLevy, 2001; Ho, 2009; Malmendier, Tate, 2010).

The presence of these heuristics effects such as emotional bias pushes individuals to acquire emotional skills and regulate their emotions. Indeed, this research has encouraged researchers to use the concept of emotional intelligence to augment the unsatisfactory notion of IQ and to consider skills in emotional regulation as real capital. Mayer and Salovey (1997) showed that emotional intelligence plays an important role not only in regulating and controlling emotions but also in developing intellectual and cognitive processes (Lopes et al, 2005; Song et al, 2010). According to Anderson (1983), the absence of this skill implies an uncertainty that may lead an individual such as a CEO to react conservatively or refuse to make any decision (Trautmann, Veider, \& Wakker, 2009) that is likely to alter his current status.

Our idea for this research was inspired by the behavioral approach, and the paper aims to highlight the role of emotional intelligence in minimizing the behavioral biases (optimism, loss aversion and overconfidence) and improving CEO financial policies (choice of capital structure, investment decisions and dividend policies).

The article is structured as follows: Section 2 presents the related literature and the theories that motivated the work, and Section 3 discusses the empirical strategies that were adopted. Section 4 discusses the main results, and Section 5 concludes.

\section{Literature Review and Hypothesis}

\subsection{Emotional intelligence concept (IE)}

The study of the positive role of emotions in the decision-making process leads us to the concept of emotional intelligence (IE). Indeed, emotional intelligence is at the heart of the skills portfolio of an effective leader. Some authors even consider it a key driver of organizational performance (Côté et al., 2010; Goleman, 2001; Kilduff, Chiaburu, \& Menges, 2011; Song et al., 2010). In this section, we review the literature on emotional intelligence.

\subsubsection{Definition}

Salovey and Mayer (1990), who originally used the term "emotional intelligence", initially defined it as a form of intelligence that involves the ability to monitor one's own and others' feelings and emotions, to discriminate among them and to use this information to guide one's thinking and actions (Salovey \& Mayer, 1990).

Later, the authors revised their definition of emotional intelligence, and the current characterization is now the most widely accepted. Emotional intelligence is thus defined as the ability to perceive emotion, integrate emotion to facilitate thought, understand emotions, and regulate emotions to promote personal growth (Mayer \& Salovey, 1997).

On the most general level, emotional intelligence is the ability to recognize and manage emotions in one and others (Goleman, 2001).

\subsubsection{Emotional intelligence model}

Each theoretical paradigm conceptualizes emotional intelligence from one of two perspectives: ability models or mixed models (Bar-On, 2002; Goleman, 1997). Ability models regard emotional intelligence as a pure form of mental ability and therefore as a pure intelligence. In contrast, mixed models of emotional intelligence combine mental ability with personality characteristics such as optimism and well-being (Mayer, 1999). Currently, the only ability model of emotional intelligence is that proposed by Mayer and Salovey. Two mixed models of emotional intelligence have been proposed, each with a somewhat different conception. In this section, we present Mayer and Salovey model, upon which our empirical work is based.

\section{Salovey and Mayer: An Ability Model of Emotional Intelligence}

Mayer and Salovey conception of emotional intelligence was included within a model of intelligence, that is, its goal was to define emotional intelligence within the confines of the standard criteria for a new intelligence (Mayer, Salovey, \& Caruso, 2008). The authors proposed that emotional intelligence is comprised of two areas: experiential (the ability to perceive, respond, and manipulate emotional information without necessarily understanding it) and strategic (the ability to understand and manage emotions without necessarily perceiving feelings well or fully experiencing them). Each area is further divided into two branches that range from basic psychological processes to more complex processes integrating 

thetic vision, and is able to comprehend an overall situation. In other words, a high level of emotional intelligence reduces CEO suggestibility toward behavioral biases and limits biased assessments based on underinvestment.

Zeidner, Matthews and Roberts (2004) demonstrated the positive role that emotional intelligence can play in reducing the amount of optimism bias among executives. The authors argued that the success of individuals depends on their ability to control their emotions, which implies a positive correlation between emotional intelligence and the effectiveness of CEOs' financial policies.

H1: The larger the decrease in CEOs' optimism (demonstrating a high level of emotional intelligence), the more effective a firm's financial policies.

\subsubsection{Emotional intelligence, loss aversion and firm's} financial policy

Most studies on the significance of a human performance model concerning emotional intelligence criticize the theory that an individual's knowledge, abilities, and specific skills determine the performance of an organization. This perspective considers that the emotions of individual employees have greater significance than their intellectual abilities in determining their long-term performance (Song et al, 2010). A CEO's high level of emotional intelligence improves his ability to process information, diagnose situations and evaluate alternatives. It should be noted that the choice of a time horizon is positively correlated with a company's growth opportunities and not with the duration of a CEO's mandate, which implies a positive correlation between emotional intelligence and the effectiveness of a CEO's financial policies.

Emotional self-awareness and understanding the triggering factors for emotions allow managers to select more appropriate actions and improve the effectiveness of CEO's financial policies. For Damasio (1994), emotional intelligence improves the quality of decisions as well as the ability to adapt by allowing the harmonization of different cognitive processes. Some authors even regard emotional intelligence as an essential, crucial motor of organizational performance (Goleman, 2001).

Huy (2002) showed that emotional intelligence develops through listening skills, communication, con- flict management and leadership. Development capabilities reduce CEOs' suggestibility to behavioral biases and ensure the effectiveness of CEOs' decisions. Emotional intelligence reduces the feeling of loss aversion and encourages a leader to issue new shares. It allows a leader to effectively exploit the productive capacity of a business, including a firm's financial policy.

Kafetsios and Zampetakis (2008) demonstrated that emotional intelligence has a significant, direct influence on job satisfaction. Thus, well-managed emotions allow individuals to achieve the optimum use of their resources and capabilities. These skills are essential to adapt to specific situations. In other words, a high level of emotional intelligence improves cognitive flexibility of leaders, reducing their suggestibility to behavioral biases (loss aversion) and encouraging them to make less biased decisions. These factors imply that there is a positive correlation between emotional intelligence and the effectiveness of CEOs' financial policies.

H2: The larger the decrease in CEOs' loss aversion (demonstrating a high level of emotional intelligence), the more effective a firm's financial policies.

\subsubsection{Emotional intelligence, overconfidence and firm's financial policies}

A growing body of empirical evidence suggests that emotional intelligence correlates robustly with a variety of outcomes that signal social emotional success, including more frequent positive effects, higher self esteem, greater life satisfaction, increased social engagement, and a greater sense of well-being (Goleman, 2001; Gond \& Mignonac, 2002; Hess, 2003; Zeidner \& Olnick-Shmesh, 2010). In other words, emotionally intelligent CEOs are less susceptible to the effects of emotional biases such as overconfidence.

Some studies have, suggested that individuals who are endowed with a high level of emotional intelligence are more aware of the factors that influence their positive and negative emotions (Karim, 2010; Rode et al., 2007), which reduces the presence of emotional bias and encourages effective strategies.

Siu (2009) demonstrated the presence of a positive correlation between emotional intelligence and effective decision-making. The author argued that a high level of emotional intelligence is positively associated 
with low susceptibility to behavioral biases (overconfidence). Self-awareness and an understanding of others' emotions allow leaders to gain the confidence of stakeholders. This emotional regulation facilitates the negotiation of contracts with third parties, reduces transaction costs and ensures efficient operations. These conclusions simply a positive correlation between emotional intelligence and the effectiveness of CEOs' financial policies.

Karim (2010) postulated that the level of emotional intelligence is an indicator of individuals' effectiveness. The author showed that emotional competencies are necessary for the proper operation of many of our faculties, such as memory, reasoning, decision-making and social adaptation. Haag and Laroche (2009) found that emotionally intelligent leaders communicate their visions to their teams better and generate more convincing ideas. A high level of emotional intelligence allows a leader to generate and maintain mutual trust with all of a company's stakeholders. Emotional intelligence facilitates the achievement of a CEO's strategic forecasts through optimal financial policies.

H2: The greater the decrease in CEOs' overconfidence (demonstrating a high level of emotional intelligence), the more effective a firm's financial policies.

\section{Research method}

\subsection{Data}

Our empirical study is based on quantitative research, and we use a questionnaire as our method of data collection. Our questionnaire consists of four main parts based on the treated areas in the theories:

- The first part aims to identify the company.

- The second part focuses on determining the CEO's emotional intelligence level.

- The third part determines the CEO's loss aversion level.

- The fourth part provides the CEO's level of optimism and seeks to show the CEO's level of overconfidence.

The questionnaire is addressed to the CEOs of Tunisian companies. The selected sample consists of 100 managers of industrial and commercial companies listed on the Tunisian stock exchange in 2010 (28 companies) and 82non-listed companies.
Our choice of listed companies is justified by the fact that these companies are assumed to be the most efficient, and they meet several conditions necessary for the reliability of our study, including diffuse shareholders and an important role for the board in the companies' ownership structure; these factors consequently increase the validity of our assumptions.

We decided to exclude financial firms: banks, insurance companies and investment companies, both for development and portfolio management. These companies have different characteristics from nonfinancial businesses and their exclusion avoids correlation effects specific to a specific sector.

To obtain a representative sample of the Tunisian market, we added other unlisted companies.

\subsection{Variables' measurement}

The objective of this section is to explain the measurement of the variables'

\subsubsection{Choice of capital structure}

The Appropriate measures in the literature to evaluate three methods of financing are:

\subsubsection{Internally generated resources (cash flow)}

Studies within the framework of the financial theories of investments have resorted to many measures of internal resources. Cash flow (CF) represents the cash flow generated by a business' activities and, is one of the most appropriate measures (Lehen \& Poulsen, 1989; Naoui, Elgaied, \& Bayoudh, 2008).

\section{$\mathrm{CF}=$ Net income + Depreciation - Dividends}

\section{Cash flow rate $(\mathrm{RCF})=\mathrm{CF} /$ Total Assets}

To show whether leader chooses to use internally generated resources, we use the change in cash flow rate. A negative change indicates the use of internal resources.

Cash flow rate variation $=\mathrm{RCF}_{\mathrm{N}}-\mathrm{RCF}_{\mathrm{N}-1} / \mathrm{RCF}_{\mathrm{N}-1}$ (1).

\subsubsection{Debt level}

A variety of variables are used to measure the level of a company's debt. Measures such as the total debt service ratio have been used by several authors (A. Hovakimian, G. Hovakimian, \& H. Tehranian, 2004). Others have used the debt ratio in the medium and long term (Myers, 2001). The debt ratio in the short term was also used by Titman (1984). 
Table 1. Visited Companies

Initial BVMT sample for 2010

Financial firms

Other non-financial firms

Insufficient data on emotional intelligence

Insufficient data on the composition of the boards of directors

As part of our analysis, we propose to use the debt ratio to measure the debt level. This ratio is calculated by: Leverage ratios $(\mathrm{LEV})=($ Total debt $/$ Total assets $)$

This measure was also used by Benkraiem (2008), Demaria and Dufour (2007), Jarboui and Olivero (2008), Koh (2003), Sahut and Gharbi (2008).

To show whether a manager uses debt, we use the change in the debt ratio. A positive change indicates the use of debt.

Leverage ratios variation $=\mathrm{LEV}_{\mathrm{N}}-\mathrm{LEV}_{\mathrm{N}-1} / \mathrm{LEV}_{\mathrm{N}-1}$ (2).

\subsubsection{Equity level}

This variable is measured by the value of equity in a company's balance sheet. To show whether leader chooses to increase capital, we use the variation in the percentage of investment. A positive change indicates an increase of capital.

\section{Level of capital invested (LCI) $=$ Equity / Total assets} Level of capital invested variation $=\mathrm{LCI}_{\mathrm{N}}+$

- $\mathrm{LCI}_{\mathrm{N}-1} / \mathrm{LCI}_{\mathrm{N}-1}$

A financial decision has 7 possibilities:

- 1 if the manager chooses internally generated resources: a positive variation in the cash flow rate.

- 2 if the manager chooses debt: a positive variation in the leverage ratio.

- 3 if the manager chooses to increase capital: a positive variation in the level of invested capital.

- 4 if the manager chooses internally generated resources + debt: a positive variation in the cash flow rate and debt ratios.

- 5 if the manager chooses internally generated resources + an increase in capital: a positive variation in the cash flow rate and the level of capital invested.
- 6 if the manager chooses debt + an increase in capital: a positive variation in the leverage ratio and the level of invested capital.

- 7 if the manager chooses internally generated resources + debt+ an increase in capital: a positive variation in the cash flow rate, the leverage ratio and the level of invested capital.

\subsubsection{Firms' investment decisions}

The purpose of this article is to demonstrate the impact of emotions on firms' investment decisions (based on the investments' nature, level and horizon). The appropriate measures IN the literature to evaluate investment decisions are:

\subsubsection{Assets specificity}

In this study, we use the degree of assets intangibility as a proxy of the specific investments. The degree of assets intangibility can be appreciated on many levels. In studies devoted to the development of intangible investments in France, the Bank of France and the Ministry of Industry have often used the ratio of intangible assets to tangible assets. In Tunisia, as in France, the accounting records for intangible assets are derived from the capitalization of such expenses. However, the unavailability of information legitimizes the use of the amount of intangible assets as presented in the balance sheet, although these amounts are often considered doubtful because they are the result of discretionary choices by a company's leaders. Akin to the French context, the measurement of intangible capital in the Tunisian context has the same problems, which leads us to adopt accounting.

Based on the above discussion and the availability of data for Tunisian companies, we offer the following indicator of the degree of intangible expenses: 


\section{Asset specificity rate (ASR) $=$ \\ = Intangible assets / Asset accounting}

(4)

This measure was also used by Cazavan-Jeny (2004), Moussu and Thibierge (1997), and Thibierge (2001).

\subsubsection{Investment level}

In this study, we use the presence of free cash flow and growth opportunities as two indicators of overinvestment (low future investment opportunities and free cash flow) or underinvestment (low free cash flow and future investment opportunities). The literature differs on how to measure free cash flow as conceptualized by Jensen (1986). In general, however, free cash flow is defined as operating income before depreciation, interest expenses and taxes, as well as dividends paid (Gul \& Tsui, 1998; Jaggi \& Gul, 1999; Lehen \& Poulsen, 1989) divided by book value of total assets to account for effects related to size (Lang, Schulz, \& Walkling, 1991).

Free cash flow rate $($ FCFR $)=$

$=$ Operating profit $/$ Total assets

Future investment opportunities are measured by Tobin's Q (Skinner, 1993). Tobin's Q is defined as the ratio of a firm's market value to the replacement value of its assets (Griliches, 1981; Lindenberg \& Ross, 1981; Megna \& Klock, 1993; Skinner, 1993). If the value of Tobin's Q is greater than one, the company has profitable investment opportunities and vice versa. In our study, we use an approximation of Tobin s Q that is, calculated as follows (Chung \& Pruitt, 1994):

$Q_{i t} \cong \frac{M V S_{i t}+D_{i t}}{A_{i t}}$

where MVS represents- the market value of common and preferred shares; D is the- book value of debt, defined as current liabilities plus long-term debt plus inventories minus current assets; and $\mathrm{A}$ is- total assets.

\subsubsection{Investment horizon}

Referring to the theory of agency, leaders have an obligation to obtain results in short horizons. Their wealth is tied to the firm's performance during the duration of their mission, which is the period when they run the firm. These leaders prefer short-term investment projects to quickly determine the performance of these investments and reduce uncertainty about their own value on the labor market.

In this study, we use the rate of investment operations (industrial and commercial assets) as an indicator of the investment horizon.

\section{Capital expenditure rate $(\mathrm{CER})=$}

$=$ Operating assets $/$ Total assets

This measured was used by C. Chang, A. C. Lee and C. F. Lee (2009), Cliche (2000), Gervais Heaton and Odean (2002), Malmendier and Tate (2005).

An investment decision has 9 possibilities:

- 1 if the manager chooses a specific investment: a positive variation in the rate of asset specificity.

- 2 if the manager chooses overinvestment: low future investment opportunities and free cash flow

- 3 if the manager chooses underinvestment: low free cash flow and future investment opportunities.

- 4 if the manager chooses long-term investment: a negative variation in the rate of capital expenditures.

- 5 if the manager chooses short-term investments: a positive variation in the rate of capital expenditures.

- 6 if the manager chooses (overinvestment+ longterm investment): a negative variation in the rate of capital expenditures, low future investment opportunities and free cash flow.

- 7 if the manager chooses (underinvestment+ short-term investments): a positive variation in the rate of capital expenditures, low free cash flow and future investment opportunities.

- 8 if the manager chooses (specific investment+ overinvestment + long-term investment): a positive variation in the rate of asset specificity, a negative variation in the rate of capital expenditures, low future investment opportunities and free cash flow.

- 9 if the manager chooses specific investment+ underinvestment + long-term investment): a positive variation in the rate of asset specificity, low free cash flow, future investment opportunities and a negative variation in the rate of capital expenditures.

\subsubsection{Choice of dividend policy}

The variable used to measure the dividend level is the distribution rate (Agrawal \& Jayaraman, 1994; Rozeff, 1982). The advantage of the distribution rate is that the 
information is provided in terms of retention of earnings and, therefore, whether the flow (the retention rate is equal to 100 in the payout ratio).

\section{Payout ratio $=$}

$=$ Dividend per share / Earnings per share

\subsubsection{Emotional bias}

The questionnaire focuses on evaluating and scoring the three emotional biases (risk aversion, optimism and overconfidence). The questions were inspired from the questionnaires formulated by the Fern Hill and Industrial Alliance companies.

Emotional bias has 2 possibilities:

- 1 if the individual has a high level for each bias.

- 0 if the individual does not have has a high level for each bias.

\subsubsection{The emotional intelligence measure: SSREI \\ TEST}

In this study, we generated a pool of 18 items (derived from Schutte et al, 1998, i.e.,the SSREI test) based on the theoretical model of emotional intelligence developed by Salovey and Mayer (1990). Each item selected for the initial pool of 18 items should reflect an adaptive tendency toward emotional intelligence within the model's framework. The respondents used a 5-point scale, whereby " 1 " represents "strongly disagree" and "5" represents "strongly agree," to indicate the extent of the fit for each item described. The entire model is represented by the items. Each of the first four authors independently evaluated each item for fidelity to the relevant construct, clarity and readability. Some of the items were deleted, while others were added or revised before they were pilot tested by asking several individuals to complete the questionnaire and note any unclear elements. This process eventually resulted in a pilot-tested pool of 18 items.

\subsubsection{Control variables}

Static trade-off theory (STT) and pecking order theory (POT) are the theories that address the issue of a firm's financial decisions. The factors that explain a firm's financial decisions mainly concern the cost, size, level of risk, growth opportunities, and the structure of the assets and the business (Booth et al, 2001).

We include three control variables in our model that explain the effectiveness of choices regarding a compa- ny's financial structure. These variables are proxies for profitability, firm size and growth opportunities.

We include three control variables in our study that explain the effectiveness of the choice of the capital structure of a company. These variables are also proxies for profitability, firm size and growth opportunities.

\subsubsection{Profitability}

More profitable firms have, ceteris paribus, more internally generated resources to fund new investments. If their managers follow a pecking order, they will be less likely to seek external financing (Fama \& French, 2002). Thus, on average, these firms' leverage ratios will be lower. In trade-off models, on the other hand, this relationship is inverted. More profitable firms are less subject to bankruptcy risks, ceteris paribus. Hence, their expected bankruptcy costs are reduced, and they can make more use of the tax shields provided by debt, thus choosing a position of greater leverage. We use the ratio of return on assets, ROA, to measure this variable:

ROA=Earnings before interest, taxes, and depreciation divided by Total assets, lagged one year

(9).

\subsubsection{Firm size}

Studies have suggested that the probability of bankruptcy is lower in larger firms; therefore, their debt capacity is higher than smaller firms, with all else being equal. However, fixed transaction costs can make new stock issues unattractive to small corporations, stimulating them to issue debt (Hovakimian et al, 2004; Rajan and Zingales, 1998).

Indeed, most studies have used total assets or turnover as a measure for firm size (Bujaki \& Richardson, 1997). In this paper, we measure firm size through the $\log$ of the firm's total assets (LNSIZE).

\subsubsection{Future investment opportunities}

It has been argued that future profitable investment opportunities can influence corporate financing decisions in different ways. In the context of the pecking order theory, firms that have many investment opportunities and believe that their stock (and risky bonds) is undervalued by the market may choose a capital structure with less debt. If these firms maintained high debt ratios, they would be forced to distribute the precious cash flows generated by their business and could 
Table 2. Operational definitions of variables

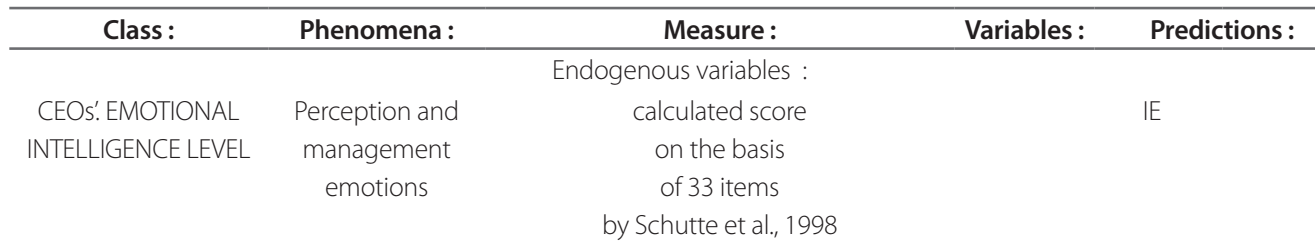

\begin{tabular}{|c|c|c|c|c|c|}
\hline \multicolumn{6}{|c|}{ Exogenous variables: } \\
\hline & & & & Yes & No \\
\hline Optimism & $\begin{array}{l}\text { Directors } \\
\text { overestimate } \\
\text { capacity of their } \\
\text { firms }\end{array}$ & The questionnaire's obtained score & $\mathrm{OP}$ & - & + \\
\hline Lost aversion & $\begin{array}{l}\text { Loss rumination } \\
\text { and reputation }\end{array}$ & The questionnaire's obtained score & LA & - & + \\
\hline Overconfidence & $\begin{array}{l}\text { Directors } \\
\text { overestimate } \\
\text { their personal } \\
\text { competences }\end{array}$ & The questionnaire's obtained score & OVER & - & + \\
\hline \multirow[t]{3}{*}{$\begin{array}{l}\text { Choice of capital } \\
\text { structure }\end{array}$} & $\begin{array}{l}\text { Internally } \\
\text { generated } \\
\text { resources(cash } \\
\text { flow) }\end{array}$ & $\begin{array}{c}\text { CF }=\text { Net income }+ \text { Depreciation }- \\
\text { Dividend } \\
\text { Cash flow rate }(\mathrm{RCF})=\mathrm{CF} / \text { Total assets } \\
\text { ) } \\
\text { Cash flow rate variation }=\text { RCFN- RCFN-1 } \\
/ \text { RCFN-1 }\end{array}$ & CF & + & - \\
\hline & Debt level & $\begin{array}{c}\text { Leverage ratios }(\mathrm{LEV})=(\text { Total debt } / \\
\text { Total assets }) \\
\text { Leverage ratios variation }=\text { LEVN- LEVN-1 } \\
\text { / LEVN-1 }\end{array}$ & LEV & + & - \\
\hline & Equity level & $\begin{array}{l}\text { Level of capital invested }(\mathrm{LCl})=\text { Equity / } \\
\text { Total assets } \\
\text { Level of capital invested variation = LCIN- } \\
\text { LCIN-1 / LCIN-1 }\end{array}$ & EQ & + & - \\
\hline \multirow[t]{4}{*}{ Investment decision } & Asset specificity & $\begin{array}{l}\text { Asset specificity rate }(\mathrm{ASR})=\text { Intangible } \\
\text { assets / Asset accounting. }\end{array}$ & AS & + & - \\
\hline & Investment level & $\begin{array}{c}\text { Free cash flow rate }(F C F R)=\text { Operating } \\
\text { profit / Total assets. and }\end{array}$ & INL & + & - \\
\hline & & $Q_{i t} \cong \frac{M V S_{i t}+D_{i t}}{A_{i t}}$ & & & \\
\hline & $\begin{array}{l}\text { Investment } \\
\text { horizon }\end{array}$ & $\begin{array}{c}\text { Capital expenditure rate } \\
(\text { CER })=\text { Operating assets } / \text { Total assets }\end{array}$ & $\mathrm{INH}$ & + & - \\
\hline
\end{tabular}


Table 2. Continued

\begin{tabular}{|c|c|c|c|c|}
\hline Class: & Phenomena: & Measure: & Variables: & Predictions: \\
\hline \multicolumn{5}{|c|}{ Control variables: } \\
\hline Profitability & $\begin{array}{c}\text { Reports on } \\
\text { the company's } \\
\text { ability to meet its } \\
\text { commitments }\end{array}$ & $\begin{array}{c}\mathrm{ROA}=\text { Earnings before interest, taxes, } \\
\text { and depreciation divided by total assets, } \\
\text { lagged by one year }\end{array}$ & PF & + \\
\hline Firm size & $\begin{array}{l}\text { Firms signaled } \\
\text { performance }\end{array}$ & Ln (total assets) & LNSIZE & + \\
\hline $\begin{array}{c}\text { Future investment } \\
\text { opportunities }\end{array}$ & $\begin{array}{l}\text { Indicates the } \\
\text { productive } \\
\text { capacity of the } \\
\text { company }\end{array}$ & $\begin{array}{l}\qquad Q_{i t} \cong \frac{M V S_{i t}+D_{i t}}{A_{i t}} \\
\text { MVS - market value of common and } \\
\text { preferred shares; D - book value of debt, } \\
\text { defined as current liabilities plus long- } \\
\text { term debt plus inventories minus current } \\
\text { assets; A - total assets. }\end{array}$ & $\mathrm{FIO}$ & + \\
\hline
\end{tabular}

face the need to issue undervalued securities to fund new projects. This process could, in turn, induce underinvestment. A more static version of the pecking order model, on the other hand, predicts that firms with more future opportunities will be more levered, ceteris paribus, because they need more external financing, and issuing debt is preferable to issuing new stock. (Booth et al, 2001; Naoui et al, 2008; Rajan \& Zingales, 1998).

We use the Tobin's Q to measure this variable, estimated with the approximation formula proposed by Chung and Pruitt (1994):

$Q_{i t} \cong \frac{M V S_{i t}+D_{i t}}{A_{i t}}$

Where MVS represents the - market value of common and preferred shares; D is the - book value of debt, defined as current liabilities plus long-term debt plus inventories minus current assets; and $\mathrm{A}$ is total assets.

For simplification purposes, the summary of each variable's range in the model, its name and its expected impact on the choice of capital structure are depicted in Table 2.

\subsection{Bayesian Network Method}

There are many versions of the definition of a Bayesian network, but the basic form (Pearl, 1986) can be stated as follows: a Bayesian network is a directed probability graph, connecting the relative variables with arcs, and this type of connection expresses the conditional dependence between the variables. The formal definition follows.

A Bayesian network is defined as the set of $\{D, S$, P\}, where.

(1) D is a set of variables (or nodes). In our case, D consists of the choice of capital structure, optimism, loss aversion, overconfidence, profitability, firm size and future investment opportunities.

(2) $S$ is a set of conditional probability distributions (CPD). $S=\{p(D /$ Parents(D) $/ D \in D\}$, Parents(D) $\subset \mathrm{D}$ stands for all of the parent nodes for $\mathrm{D}$, and $p(D /$ Parents(D) is the conditional distribution of variable D.

(3) $\mathrm{P}$ is a set of marginal probability distributions. $\mathrm{P}=$ $\{p(D) / D \in D\}$ stands for the probability distribution of variable $\mathrm{D}$.

In the Bayesian network, variables are used to express the events or objects. The problem can be modeled with the behavior of these variables. In general, we first calculate (or determine from expert experience) the probability distribution of each variable and the conditional probability distribution between them. Then, from these distributions, we can obtain the joint distributions of these variables. Finally, some deductions can be developed for some variables of interest using some other known variables. 
Table 3. The network variables and their values

\begin{tabular}{cl}
\hline Variables & \multicolumn{1}{c}{ Type } \\
\hline Emotional intelligence & Discreet : YES/NO \\
Dividend policy & Discreet : YES/NO \\
Investment decision & Discreet $[1 ; 2 ; 3 ; 4 ; 5 ; 6 ; 7 ; 8 ; 9]$ \\
Choice of capital structure & Discreet $[1 ; 2 ; 3 ; 4 ; 5 ; 6 ; 7]$ \\
Optimism & Discreet : YES/NO \\
Loss aversion & Discreet : YES/NO \\
Overconfidence & Discreet : YES/NO \\
Profitability & Discreet : YES/NO \\
Firm size & Discreet $[1 ; 2 ; 3]$ \\
Future investment opportunities & Discreet : YES/NO \\
\hline
\end{tabular}

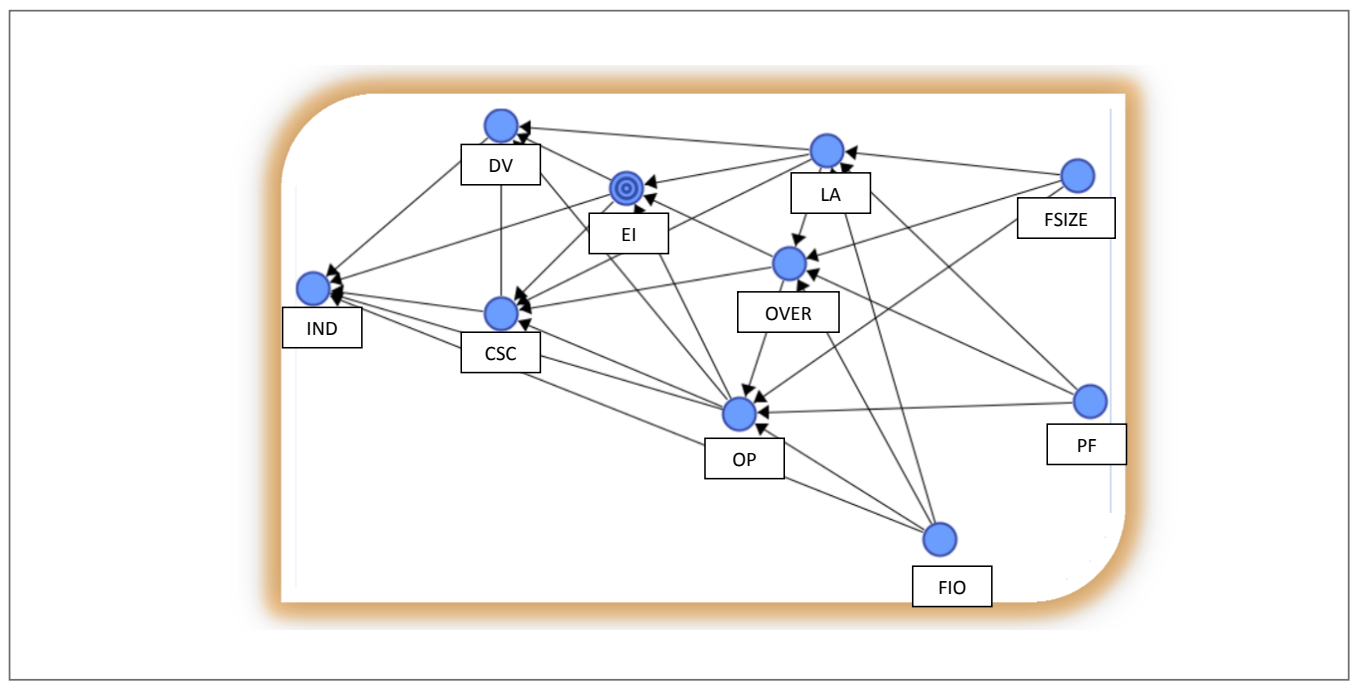

Figure 1. Relationship between CEO Emotional Intelligence and Firms'Financial Policies: Bayesian Network

In our study, we attempt to show the evolution of CEO financing policy according to the evolution of the CEO's emotions and the characteristics of his company. Thus, we must theoretically show that the company's financial policy (choice of capital structure, investment decisions and dividend policy) depends on the CEO's emotional intelligence level, the CEO's emotional biases (the CEO's optimism level, loss aversion and overconfidence), firm profitability, firm size and the firm's future investment opportunities.

\subsubsection{Define network variables and values}

The first step in building a Bayesian network expert is to list the variables recursively, starting from the target variable to the causes. Thus, we present the variables in this order in table 3. 
Table 4. The relationships analysis

\begin{tabular}{ccccc}
\hline Parentnodes & Child nodes & $\begin{array}{c}\text { Kullback- } \\
\text { Leiblerdivergence }\end{array}$ & Poids relative & Relative weight \\
\hline CSC & IND & 0,892199 & 1,0000 & $0,1840^{*}$ \\
FIO & IND & 0,696608 & 0,7808 & 0,2455 \\
OP & CSC & 0,608921 & 0,6825 & $-0,0985^{*}$ \\
LA & EI & 0,584167 & 0,6548 & $-0,7875$ \\
EI & IND & 0,366895 & 0,4112 & $0,1392^{*}$ \\
OVER & CSC & 0,290961 & 0,3261 & 0,3086 \\
DV & IND & 0,234745 & 0,2631 & $-0,0843^{*}$ \\
EI & CSC & 0,197150 & 0,2210 & 0,2392 \\
FSIZE & LA & 0,193522 & 0,2169 & $-0,3519$ \\
FSIZE & OP & 0,191295 & 0,2144 & 0,2133 \\
OP & IND & 0,174818 & 0,1959 & $-0,1089^{*}$ \\
CSC & DV & 0,156985 & 0,1760 & $-0,0293^{* *}$ \\
FIO & OVER & 0,135048 & 0,1514 & $0,0346^{* *}$ \\
PF & OVER & 0,134062 & 0,1503 & 0,1251 \\
OP & DV & 0,119795 & 0,1343 & 0,5731 \\
FSIZE & OVER & 0,108402 & 0,1215 & $0,0429^{* *}$ \\
FIO & OP & 0,097059 & 0,1088 & $-0,0688^{* *}$ \\
PF & OP & 0,096918 & 0,1086 & $0,1714^{*}$ \\
LA & CSC & 0,090661 & 0,1016 & $-0,1251^{*}$ \\
PF & LA & 0,077256 & 0,0866 & $-0,1662^{*}$ \\
OP & El & 0,074753 & 0,0838 & 0,2206 \\
LA & OVER & 0,053792 & 0,0603 & $-0,1555^{*}$ \\
FIO & LA & 0,044916 & 0,0503 & $-0,0308^{* *}$ \\
OVER & OP & 0,042004 & 0,0471 & $-0,0159^{* * *}$ \\
EI & DV & 0,036821 & 0,0413 & $0,0057^{* * *}$ \\
OVER & El & 0,020380 & 0,0228 & 0,2053 \\
LA & DV & 0,005654 & 0,0063 & $0,0655^{* *}$ \\
\hline & & & \\
\hline & & & \\
\hline
\end{tabular}

Notes:

a. Kullback-Leibler close to 1: important correlation between the variables

b. Relative weight close to 1 : important correlation between the variables.

c. Pearson correlation:*, , , ${ }^{* *}$ at $10 \%, 5 \%$, and 1 levels respectively.

\subsubsection{Graphic model}

The second step in the construction of a Bayesian network is to express the relationships between the variables. The BayesiaLab takes the database as a discrete entry process without sampling the data. The constructed Bayesian network is the result for the entire database. According to the data that we accumulated through the questionnaire; we have established the relationships in Figure 1.

\section{Empirical results}

\subsection{Analysis of the relationships discovered}

The relationships between the variables in the database are directed at the parent node child node. Each relationship is composed of three different measures: the Kullback-Leibler, the relative weight and the Pearson correlation (direction of relationship). 
The relative weight scale is 0 to 1 . Thus, Table 4 shows the relationship analysis results between the variables across the network and their Pearson correlations.

The test shows a positive correlation $(\beta=0.1848)$ between the choice of capital structure and investment decisions. The results also show the presence of a strong and non-significant relationship between future investment opportunities and investment decisions (Kullback-Leibler $=0.7202 /$ weight ratio $=$ $0.7375 / \beta=0.2702$ ). In addition, the CEO's choice of capital structure is negatively correlated with the CEO's optimism rate $(\beta=-0.0985)$ and level of loss aversion $(\beta=-0.1251)$. Investment decisions are positively correlated with the CEO's overconfidence level ( $\beta=0.1531)$ and negatively correlated with the CEO's loss aversion rate $(\beta=-0.0912)$ and optimism level ( $\beta$ $=-0.1089)$. The relationships analysis shows a negative correlation between a firm's choice of capital structure and dividend distributions $(\beta=-0.0293)$. Finally, dividend distributions are positively correlated with the CEO's loss aversion level $(\beta=0.0655)$ and optimism level $(\beta=0.5731)$ and negatively correlated with investment decisions $(\beta=-0.0843)$.

The CEO's emotional intelligence level is positively correlated, but not significantly, with a firm's choice of capital structure (Kullback-Leibler $=0.1971 /$ weight ratio $=0.2210 / \beta=0.2392$ ). This result confirms our theoretical predictions ( $\mathrm{H} 1, \mathrm{H} 2$ and $\mathrm{H} 3)$ and shows the positive effect of the CEO's emotional intelligence on the effectiveness of his decision.

The results show a positive ( $\beta=0.1392)$ and strong relationship (Kullback-Leibler $=0.3668$ / weight ratio $=0.4112$ ) between the CEO's emotional intelligence and firms' investment decisions.

Emotional intelligence is correlated (KullbackLeibler $=0.0368 / 0.0413=$ relative weight $)$, both positively and significantly $(\beta=0.0057)$, with a firm's dividend policy.

CEO optimism is correlated (Kullback-Leibler $=0.0747 / 0.0838=$ relative weight $)$ positively $(\beta=$ 0.2206) with the CEO's emotional intelligence level. This result shows that emotional intelligence helps to develop some behavioral biases (including optimism).

A leader's loss aversion is negatively and not significantly correlated with the leader's level of emotional intelligence $($ Kullback-Leibler $=0.5841 / 0.6548=$ relative / $\beta=-0.7875)$. This result implies that a high level of emotional intelligence minimizes the suggestibility frame work for certain behavioral biases (including loss aversion).

A leader's overconfidence is positively correlated with his emotional intelligence level (Kullback-Leibler $=0.02038 / 0.0228=$ relative $/ \beta=0.2053)$. This result shows that emotional intelligence helps to develop some behavioral biases (including overconfidence).

The relationship analysis shows that firm size affects CEOs' emotional state. Thus, firm size negatively affects a CEO's loss aversion level $(\beta=-0.3519)$ and is positively correlated with a CEO's level of optimism ( $\beta$ $=0.2133)$ and rate of overconfidence $(\beta=0.0429)$.

Future investment opportunities are positively correlated with $\mathrm{CEO}$ overconfidence $(\beta=0.0346)$ and negatively correlated with the CEO's loss aversion level $(\beta=-0.0688)$ and, level of optimism $(\beta=-0.0308)$.

Firm profitability is negatively correlated with the CEO's loss aversion rate $(\beta=-0.1662)$, optimism level ( $\beta=0.1714)$ and overconfidence $(\beta=0.1251)$.

The relationship analysis shows a negative correlation between a leader's loss aversion level and his overconfidence $(\beta=-0.1555)$.

Finally, the results also show a negative correlation between a leader's overconfidence and his optimism level $(\beta=-0.0159)$.

\subsection{Target variable analysis: emotional intelligence}

To analyze a CEO's emotional intelligence level, we choose the variable CEO emotional intelligence level (EI) as a target variable in the Bayesian network. We can then use the function that generates the analysis report for the target, the CEO's emotional intelligence level. In this report, the relationship between a CEO's emotional intelligence level and the other variables is measured with binary mutual information and the relative binary importance. The mutual information of two random variables measures the statistical dependence of these variables. It is measured in bits.

The emotional intelligence analysis shows that $49.58 \%$ of Tunisian CEOs are emotionally intelligent and $50.42 \%$ are not.

If the leader is not emotionally smart node biggest is loss aversion (relative importance $=1$ ). The other explanatory variables are choice of capital structure (relative importance $=0.5549$ ), firm size 
Table 5. Target variable analysis

\begin{tabular}{|c|c|c|c|c|}
\hline \multicolumn{5}{|c|}{$\mathrm{EI}=\mathrm{NO}(50,42 \%)$} \\
\hline Nodes & $\begin{array}{c}\text { Binary mutual } \\
\text { information }\end{array}$ & $\begin{array}{c}\text { Binary relative } \\
\text { importance }\end{array}$ & \multicolumn{2}{|c|}{ Modal value } \\
\hline LA & 0,5665 & 1,0000 & YES & $100,00 \%$ \\
\hline $\mathrm{CSC}$ & 0,3143 & 0,5549 & EQ & $37,68 \%$ \\
\hline FSIZE & 0,0795 & 0,1403 & $\mathrm{BIG}$ & $46,01 \%$ \\
\hline IND & 0,0671 & 0,1184 & UNINV & $18,02 \%$ \\
\hline OP & 0,0355 & 0,0626 & $\mathrm{NO}$ & $51,65 \%$ \\
\hline OVER & 0,0307 & 0,0542 & $\mathrm{NO}$ & $50,66 \%$ \\
\hline PF & 0,0170 & 0,0300 & NO & $63,54 \%$ \\
\hline FIO & 0,0008 & 0,0014 & YES & $54,37 \%$ \\
\hline DV & 0,0000 & 0,0000 & YES & $70,37 \%$ \\
\hline \multicolumn{5}{|c|}{$\mathrm{EI}=\mathrm{YES}(49,58 \%)$} \\
\hline Nodes & $\begin{array}{c}\text { Binary mutual } \\
\text { information }\end{array}$ & $\begin{array}{c}\text { Binary relative } \\
\text { importance }\end{array}$ & \multicolumn{2}{|c|}{ Modal value } \\
\hline LA & 0,5665 & 1,0000 & $\mathrm{NO}$ & $76,41 \%$ \\
\hline $\mathrm{CSC}$ & 0,3143 & 0,5549 & $C F+L E V$ & $27,54 \%$ \\
\hline FSIZE & 0,0795 & 0,1403 & $\mathrm{BIG}$ & $74,22 \%$ \\
\hline IND & 0,0671 & 0,1184 & AS+LTIN+UNINV & $21,77 \%$ \\
\hline OP & 0,0355 & 0,0626 & YES & $70,04 \%$ \\
\hline OVER & 0,0307 & 0,0542 & YES & $69,51 \%$ \\
\hline PF & 0,0170 & 0,0300 & YES & $51,67 \%$ \\
\hline FIO & 0,0008 & 0,0014 & YES & $57,66 \%$ \\
\hline DV & 0,0000 & 0,0000 & YES & $70,89 \%$ \\
\hline
\end{tabular}

Notes:

a. Mutual information: the amount of information given by a variable on the target value.

b. Relative importance: the importance of this variable with respect to the target value.

c. Modal value: the average value of the explanatory variable for eachtarget value.

(relative importance $=0.1403$ ), firm investment decisions (relative importance $=0.1184$ ), CEO optimism level (relative importance $=0.0626$ ), $\mathrm{CEO}$ overconfidence (relative importance $=0.0542$ ) and firm profitability (relative importance $=0.0300$ ) . Thus, the results show that $100 \%$ of CEO loss aversion, $37.68 \%$ preference for capital increase, a large size at $46.01 \%, 18.02 \%$ underinvestment preferably, $51.65 \%$ of pessimism, $50.66 \%$ of non suggestibility to overconfidence and $63.54 \%$ of low profitability imply the presence of a non-emotionally intelligent leader with $50.42 \%$.

If a leader is emotionally intelligent, the most important node is the CEO's loss aversion (relative im- portance $=1$ ). Other factors are the choice of capital structure (relative importance $=0.5549$ ), firm size (relative importance $=0.1403$ ), investment decisions (relative importance $=0.1184$ ), level of optimism (relative importance $=0.0626$ ), overconfidence (relative importance $=0.0542$ ) and profitability (relative importance $=0.0300)$. Thus, the results show that $76.74 \%$ of loss aversion, $27.54 \%$ of the torque flow preference for more debt, large size with a probability of $74.22 \%, 21.77 \%$ preference for specific investments and long-term underinvestment, an officer with CEO optimistic of $70.04 \%, 69.51 \%$ of overconfidence leader and profitability $51.67 \%$ are positively correlated with the presence of a smart leader emotionally for a probability of $49.58 \%$. 
Table 5. Target variable analysis

\begin{tabular}{cccc}
\hline \multicolumn{5}{c}{ EI = NO } \\
\hline Nodes & Optimal modality & Probability & Joint probability \\
A priori & CF & $50,42 \%$ & $100,00 \%$ \\
CSC & NO & $89,82 \%$ & $11,90 \%$ \\
OVER & & $100,00 \%$ & $8,55 \%$ \\
\hline Nodes & EI = YES & & Joint probability \\
A priori & Optimal modality & Probability & $100,00 \%$ \\
LA & & $49,58 \%$ & $37,89 \%$ \\
\hline
\end{tabular}

Notes:

a. Optimal modality: modality is maximizing the target value.

b. Probability: the prior probability of each variable.

c. Joint probability: the probability that the target variable takes the value $n$ given that the explanatory variable takes the value $\mathrm{p}$.

\subsection{Average target maximizing analysis}

After presenting all of the explanatory variables for each category of the target variable, we now introduce the variables that maximize each modality of the target variable. Thus, we use the target dynamic profile capability software (Bayesialab) to determine an a posteriori maximization of the target average. This test shows the case required to maximize the value of the target variable. Table 6 presents the dynamic profile of the CEO's emotional intelligence level (EI).

The dynamic profile analysis of the CEO's emotional intelligence provides the following results:

The increased preference for directing flow of $89.82 \%$ and decrease the level of overconfidence with probability $100 \%$ involves a decrease in the emotional intelligence level to $50.42 \%$.

The lower level of a CEO's loss aversion of $100 \%$ is positively correlated with anincrease in the CEO's emotional intelligence score of $49.58 \%$.

\section{Conclusion}

This research examines the determinants of firms' financial policiesfrom a behavioral perspective.

The theoretical analysis highlights the role of a CEO's emotional profile (emotional biases and emotional intelligence) in explaining the CEO's decisions (Bar-On, 2002; Damasio, 1994; George, 2000; Goleman, 1997;
2001; Mayer \& Salovey, 1997). Management theory has revealed the existence of strong emotional interactions between a companies'. Several studies have shown that emotions and moods play a vital role in organizations performance (Damasio, 1994). An individual's emotional state and his intuition, often addressed by one's past experiences, guide an individual in the decisionmaking process. Emotional intelligence is the ability to perceive, feel, understand and regulate one's emotions in the context of emotional and intellectual development (Mayer \& Salovey, 1997). An emotionally intelligent leader has a wide perspective, an open, synthetic vision, and a global understanding of a situation. Such an individual is aware of the emotional states of his partners and uses this knowledge as a strategic hedge against the risk of loss of his position or reputation. Hence, the specific nature of the choice, the level of investment and the investment horizon(long term or short term) are guided by a CEO's level of emotional intelligence and his suggestibility to behavioral biases. Thus, an emotionally intelligent leader has low suggestibility and low levels of behavioral biases (optimism, loss aversion and overconfidence) and chooses specific assets, underinvestment and long-term investment projects.

Thee empirical analysis is based on a survey of CEOs of large private companies in Tunisia. The analysis reveals the importance of a CEO's emotional intelligence in explaining a firm's financial policies. Indeed, the empirical analysis of the relationship between a CEO's 
emotional intelligence and the firm's choice of capital structure demonstrates the role of emotional intelligence in explaining managerial decisions. A leader's emotional intelligence is positively correlated with his overconfidence and optimism, but emotional intelligence is negatively correlated with a CEO's level of loss aversion. The increase optimism (and / or overconfidence) and decrease the level of aversion to loss of incentive to choose the combination to achieve flow more debt investment projects. This leader optimistic or overconfident opts for decisions specific investment to improve the competitiveness of its business and ensuring creation of long-term value. He prefers to underinvestment to limit the maximum recourse to external financing and how to hedge against the risk of loss of compensation or reputation.

Finally, financial policy analysis that integrates the behavioral dimension allows richer predictions from organizational theories: leaders adjust their decisions (on investments and distributions) to minimize their risk of loss of compensation or reputation. They opt for decisions that minimize agency costs, transaction costs, and cognitive costs.

\section{References}

Agrawal, A., \& Jayaraman, N. (1994). The Dividend Policies of All- Equity Firms: a direct test of the free cash flow theory. Managerial and Decision Economics, 15 (2), 139-148.

Anderson, P. A. (1983). Decision Making by Objection and the Cuban Missile Crisis. Administrative Science Quarterly, 28 (2), 201-222.

Azouzi, M. A., \& Jarboui, A. (2012). CEO Emotional Bias and Investment Decision, Bayesian Network Method. Management Science Letters, 2 (4), 12591278.

Backer, M., Ruback, R. S., \& Wurgler, J. (2004). Behavioral Corporate Finance: A Survey (Working Paper No. 10863). National Bureau of Economic Research.

Bar-On, R. (2002). Bar-On Emotional Quotient Inventory (EQ-I): Technical Manual. Toronto, Canada: Multi Heath System, 17.

Benkraiem, R. (2008). The influence of institutional investors on opportunistic earnings management. International Journal of Accounting Auditing and Performance Evaluation, 5 (1), 89-106.
Booth, L., Aivazian, V., Demirguc-Kunt, A., \& Maksimovic, V. (2001). Capital Structure in Developing Countries. Journal of Finance, 56 (1), 87-130.

Brackett, M. A., Rivers, S. E., Shiffman, S., Lerner, N., \& Salovey, P. (2006). Relating emotional abilities to social functioning: A comparison of self-report and performance measures of emotional intelligence. Journal of Personality and Social Psychology, 91 (4), 780-795.

Bujaki, M. L., \& Richardson, A. J. (1997). A Citation Trail Review of the Uses of Firm Size in Accounting Research. Journal of Accounting literature, 16, 1-27.

Carmeli, A. (2003). The relationship between emotional intelligence and work attitudes, behavior and outcomes. Journal of Managerial Psychology, 18 (8), 788-813.

Cazavan-Jeny, A. (2004). Le ratio market-to-book et la reconnaissance des immatériels- une étude du marche français [The ratio of market-to-book and recognition of intangible-a study of the French market]. Computability Control Audit, 10 (2), 99-124.

Chang, C., Lee, A. C., \& Lee, C. F. (2009). Determinants of capital structure choice: A structural equation modeling approach. The Quarterly Review of Economics and Finance, 49 (2), 197-213.

Chung, K. H. \& Pruitt, S. W. (1994). A Simple Approximation of Tobin's Q. Financial Management, 23 (3), 70-74.

Cliche, J. A. (2000). Les déterminants de la gestion des risques par les entreprises non financières: une revue de la littérature [Determinants of risk management by non-financial firms: a literature review] (Working Paper No. 00-02). Ecole des Hautes Etudes Commerciales de Montreal.

Côté, S., Lopes, P. N., Salovey, P., \& Miners, C. T. H. (2010). Emotional intelligence and leadership emergence in small groups. The Leadership Quarterly, 21 (3), 496-508.

Damasio, A. (1994). Descrates error: emotion, reason and the humain brain. New York, NY: Putnam`s Sons.

Demaria, S., \& Dufour, D. (2007). Les choix d'options comptables lors de la transition aux normes IAS/ IFRS : quel rôle pour la prudence ? [The choice of accounting options for the transition to IAS / IFRS: What role for prudence ?]. Comptabilité-Contrôle-Audit, 13 (3), 195-218. 
Fama, E. F., \& French, K. R. (2002). Testing tradeoff and pecking order predictions about dividends and debt. Review of Financial Studies, 15 (1), 1-33.

Fiori, M., \& Antonakis, J. (2011). The ability model of emotional intelligence: Searching for valid measures. Personality and Individual Differences, 50 (3), 329-334.

Fiori, M. (2009). A new look at emotional intelligence: A dual-process framework. Personality and Social Psychology Review, 13 (1), 21-44.

George, J. M. (2000). Emotions and Leadership: The role of emotional intelligence. Human Relations, 53 (8), 1027-1055.

Gervais., S., Heaton, J. B., \& Odean., T. (2002). The Positive Role of Overconfidence and Optimism in Investment Policy. [Mimeo], University Of California, Berkeley.

Goleman, D. (2001). Emotional intelligence: Issues in paradigm building. In C. Cherniss \&D. Goleman (Eds.), The emotionally intelligent workplace (pp. 13-26). San Francisco, CA: Jossey-Bass.

Golemen, D. (1997). L'intelligence émotionnelle [Emotional intelligence] (Vol. 1). Paris: Robert Laffont.

Gond, J. P., \& Mignonac, K. (2002). Émotions et hiérarchie sur le marché interne de lemploi : lévolution des conditions daccès au leadership [Emotions and hierarchy on the internal labor market: the changing conditions of access to leadership]. In M. Saboly \& L. Cailluet (Eds.), Market (s) and Hierarchy (s) (pp. 253272). Toulouse: University Press of Social Sciences.

Griliches, Z. (1981). Market value, R\&D and patents. Economic Letters, 7 (2), 183-187.

Gul, F. A., \& Tsui, J. S. L. (1998). A test of the free cash flow and debt monitoring hypotheses: Evidence from audit pricing. Journal of Accounting and Economics, 24 (2), 219-237.

Haag, C., \& Laroche, H. (2009). Dans le secret des comités de direction, le rôle des émotions : proposition d'un modèle théorique [In secret executive committees, the role of emotions: a proposed theoreticalmodel].M@n@gement,12 (2),82-117.

Hackbarth, D. (2009). Determinants of corporate borrowing: A behavioral perspective. Journal of Corporate Finance, 15 (4), 389-411.

Hawkins, S. A., Hoch, S. J., \& Meyers-Levy, J. (2001). Low-involvement learning: Repetition and coherence in familiarity and belief. Journal of Consumer Psychology, 11 (1), 1-11.
Hess, U. (2003). Emotion at Work. Rapport Bourgogne, CIRANO, Montreal, Qc.

Ho., C. R. (2009, August 15). CEO Overconfidence and Corporate Financial Distress. Available at: http:// ssrn.com/abstract=1659440.

Hovakimian, A., Hovakimian., G. and Tehranian., H. (2004), Determinants of Target Capital Structure: investment policy. [Mimeo], University Of California, Berkeley.

Huy, Q. N. (2002). Emotional Balancing of Organizational Continuity and Radical Change: the Contribution of Middle Managers. Administrative Science Quarterly, 47 (1), 31-69.

Jaggi, B., \& Gul, F. A. (1999). An analysis of joint effects of investment opportunity set, free cash flows and size on corporate debt policy. Review of Quantitative Finance and Accounting, 12 (4), 371-381.

Jarboui, A., \& Olivero, B. (2008). Le couple Risque/ Horizon temporel des investissements est-il gouverné par les institutionnels et les actionnaires dominants ? [The couple Risk / Investment Time Horizon is it governed by the institutional and controlling shareholders?]. Banque et Marchés, 93 (1), 20-34.

Jensen, M. C. (1986). Agency costs of free cash-flow, corporate finance and takeovers. American Economic Review, 76 (2), 323-329.

Kafetsios, K., \& Zampetakis, L. A. (2008).Emotional intelligence and job satisfaction: Testing the mediatory role of positive and negative affect at work. Personality and Individual Differences, 44 (3), 712-722.

Karim, J. (2010). An item response theory analysis of Wong and Law emotional intelligence scale. Procedia - Social and Behavioral Sciences, 2 (2), 4038-4047.

Kilduff, M., Chiaburu, D. S., \& Menges, J. I. (2010). Strategic use of emotional intelligence in organizational settings: Exploring the dark side. Research in Organizational Behavior, 30, 129-152.

Koh, P. S. (2003). On the association between institutional ownership and aggressive corporate earnings management in Australia. The British Accounting Review, 35 (2), 105-128.

Lang, L., Stulz, R. M., \& Walkling, R. A. (1991). A test of free cash-flow hypothesis the cash of bidder return. Journal of Financial Economics, 29 (2), 315-335. 
Lehen, K., \& Poulsen, A. B. (1989). Free Cash Flow and Stockholder Gains in Going Private Transactions. Journal of Finance, 44 (3), 771-787.

Lin, Y. C., Chen, A. S. Y, \& Song, Y. C. (2012). Does your intelligence help to survive in a foreign jungle? The effects of cultural intelligence and emotional intelligence on cross-cultural adjustment. International Journal of Intercultural Relations 36 (4), 541- 552 .

Lindenberg, E., \& Ross, S. (1981). Tobin's q ratio and industrial organization. Journal of Business, 54 (1), 1-32.

Lopes, P. N., Salovey, P., Côté, S., \& Beers, M. (2005). Emotion regulation ability and the quality of social interaction. Emotion, 5 (1), 113-118.

Malmendier, U., \& Tate, G. (2005). CEO overconfidence and corporate investment. Journal of Finance, 60 (6), 2661-2700.

Mavroveli, S., Petrides, K. V., Rieffe, C., and Bakker, F. (2007). Trait emotional intelligence, psychological well-being and peer-rated social competence in adolescence. British Journal of Developmental Psychology, 25 (2), 263-275.

Mayer, J. D., Salovey, P., \& Caruso, D. R. (2008). Emotional intelligence: New ability or eclectic traits? American Psychologist, 63 (6), 503-517.

Mayer, J. D. (1999). Emotional intelligence: popular or scientific psychology? APA Monitor, 30, 50.

Mayer, P. \& Salovey, D. J. (1997). What is emotional intelligence? In P. Salovey, D. J. Sluyter (Eds.), Emotional Development and Emotional intelligence: Educational Implications (pp. 3-31). New York, NY: Basic Books.

Megna, P., \& Klock, L. (1993). The impact of intangible capital on Tobin's Q in the semiconductor industry. American Economic Review, 83 (2), 265-269.

Mount, C., \& Downton, C. (2006). Alzheimer disease: Progress or profit? Nature Medicine, 12 (7), 780-784.

Moussu, C., \& Thibierge, C. (1997, September-October). Politique financière, opportunité d'investissement et actifs immatériels en Europe : théorie et étude empirique [Financial policy, investment opportunity and intangible assets in Europe: theory and empirical study]. In Banque et Marchés no 30. Paper presented at the 8th International Conference IAAER - 18th Congress of the AFC, 6-21.
Myers, S.C. (2001). Capital structure. Journal of Economic Perspectives, 15 (2), 81-102.

Naoui, K., Elgaied, M., \& Bayoudh, F. (2008). Internal Finance and Investment: Asymmetric Information vs. Managerial Discretion. Retrieved from http:// ssrn.com/abstract $=1118416$

Pearl, J. (1986). Fusion, Propagation, and Structuring in Belief Networks. Artificial Intelligence, 29 (3), 241-288.

Rajan, R., \& Zingales, L. (1998). Power in a Theory of the Firm. Quarterly Journal of Economics, 113 (2), 387-432.

Rode, J. C., Mooney, C. H., Arthaud-Day, M. L., Near, J. P., Baldwin, T. T., Rubin, R. S., \& Bommer, W. H. (2007). Emotional intelligence and individual performance: Evidence of direct and moderated effects. Journal of Organizational Behavior, 28 (4), 399-421.

Rosete, D., \& Ciarrochi, J. (2005). Emotional intelligence and its relationship to workplace performance outcomes of leadership effectiveness. Leadership \& Organisational Development Journal, 26 (5), 388-399.

Rozeff, M. S. (1982). Growth, Beta and Agency Costs as Determinants of Dividend Payout Ratio. Journal of Financial Research, 5(3), 249-259.

Sahut, J.M., \& Gharbi, O. (2008). Investisseurs institutionnels et valeur de la firme [Institutional investors and firm value] (Working Paper No. 00645361]. University of Poitiers \& University Paul Cézanne.

Salovey, P., \& Mayer, J. D. (1990). Emotional Intelligence. Imagination, Cognition, and Personality, 9 (3), 185-211.

Schutte, N. S., Malouff, J. M., Hall, L. E., Haggerty, D. J., Cooper, J. T., Golden, C. J., \& Dornheim, L. (1998). Development and validation of a measure of emotional intelligence. Personality and Individual Differences, 25 (2), 167-177.

Siu, A. F. Y. (2009). Trait emotional intelligence and its relationships with problem behavior in Hong Kong adolescents. Personality and Individual Differences, 47 (6), 553-557.

Skinner, D. (1993). The investment opportunity set and accounting procedure choice: Preliminary evidence. Journal of Accounting and Economics, 16 (4), $407-445$. 
Song, L. J., Huang, G. H, Peng, K. Z., Law, K. S., Wong, C. S., \& Chen, Z. (2010). The differential effects of general mental ability and emotional intelligence on academic performance and social interactions. Intelligence, 38 (1), 137-143.

Thibierge, C. (2001). Actifs immatériels, valorisation boursière et contrainte d'endettement : étude empirique sur les marchés français et espagnol [Intangible assets, market capitalization and debt constraint: An empirical study of French and Spanish markets]. International Congress of the French Finance Association, Namur, 28-30. Retrieved from. http://www.fundp.ac.be/eco/affi2001/main.html

Titman, S. (1984). The effect of capital Structure on a firm's liquidation decision. Journal of Financial Economics, 13 (1), 137-151.

Trautmann, S. T., Vieider, F. M., \& Wakker, P. P. (2009). Preference reversals for ambiguity aversion. Management Science, 57 (7), 1320-1333.

Yoo, S. H., Matsumoto, D., \& LeRoux, J. A. (2006). The influence of emotion recognition and emotion regulation on intercultural adjustment. International Journal of Intercultural Relations, 30 (3), 345-363.

Zeidner, M., Matthews, G., \& Roberts, R. D. (2004). Emotional Intelligence in the Workplace: A Critical Review. Applied Psychology: An International Review, 53 (3), 371-399.

Zeidner, M., \& Olnick-Shemesh, D. (2010). Emotional intelligence and subjective well-being revisited. Personality and Individual Differences, 48 (4), 431-435. 
